\title{
RECOVERY OF THE FUR SEAL POPULATION AT MACQUARIE ISLAND
}

\author{
by P. D. Shaughnessy, G. L. Shaughnessy and L. Fletcher
}

(with four tables, six text-figures and two plates)

SHAUGHNESSY, P.D., SHAUGHNESSY, G.L. \& FLETCHER, L., 1988 (viii): Recovery of the fur seal population at Macquarie Island. Pap. Proc. R. Soc. Tasm., 122(1): 177-187, 2 pl. Papers presented at the Macquarie Island Symposium, Hobart, May 1987. https://doi.org/10.26749/rstpp.122.1.177

ISSN 0080-4703. CSIRO Division of Wildlife and Ecology, PO Box 84, Lyneham, A.C.T., Australia 2602; 25 French Street, Hackett, A.C.T., Austraiia 2602; and Antarctic Division, Channel Highway, Kingston, Tasmania, Australia 7150.

Fur seals at Macquarie Island were harvested indiscriminately from the time of its discovery in July 1810 until the supply of animals was exhausted. The identity of the original fur seal is unknown and no specimens exist.

The New Zealand fur seal Arctocephalus forsteri has been recorded at the island since 1948 when Australian National Antarctic Research Expeditions (ANARE) began there. Numbers have increased slowly to about 1200 animals, most of them on North Head peninsula. The species is present throughout the year but does not breed on the island.

Breeding colonies of the subantarctic and antarctic fur seals, A. tropicalis and A.gazella, werefirst recognised in Goat Bay and Secluded Beach on North Head peninsula in 1981-82. These species can generally be distinguished from each other and $A$. forsteri on the basis of externalcharacters and vocalisations. A.tropicalis has not previously been reported as breeding in Australian waters; $A$. gazella breeds also at Heard Island.

In the 1985-86 and 1986-87 summers, the two groups of fur seals (non-breeders and breeders) were equally prevalent on North Head peninsula until late December, when numbers of the non-breeders increased markedly and numbers of the breeders decreased slightly.

In these two summers 30 and 37 pups were recorded. In 1986-87, the median pupping date was 10 December. Pups were born in six territories, four of which were held for most of December by $A$. tropicalis bulls and contained $86 \%$ of the pups. A. gazella bulls were smaller than A.tropicalis bulls. Almost all of the cows were identified as A. gazella, only a few A. tropicalis cows being recognised.

Key Words: fur seals, subantarctic fur seals, antarctic fur seals, New Zealand fur seals, Macquarie Island.

\section{INTRODUCTION}

In the last century, southern fur seals (Arctocephalus spp.) were severely overharvested at most subantarctic islands; at Macquarie Island they were exterminated ten or so years after the island was discovered in July 1810 . The number of fur seals harvested there is unknown but, on the basis of shipping records documented by Cumpston (1968), Shaughnessy \& Fletcher (1987) estimated that as many as 193300 were taken.

The specific identity of the original fur seals is unknown, there being no specimens or records other than the sealers' name "upland seal". Three species are now found at the island, subantarctic (A. tropicalis), antarctic (A. gazella) and New Zealand $(A$. forsteri). Of these, the subantarctic fur seal is most likely to have been the original, but it is not impossible either that this one unknown species became extinct, or that there were two (or more) species at the island originally (Shaughnessy \& Fletcher 1987).
Few fur seals were recorded at Macquarie Island in the period 1820 to 1948. Gwynn (1953) implied that small numbers were seen by the first ANARE party in 1948, and he recorded 50 in April 1949, which he identified as New Zealand fur seals.

An annual census has been conducted on North Head peninsula since 1950 , showing a steady increase to between 800 and 1000 in the period 1982 to 1987 . Newborn (black) pups were first seen in 1955 (Csordas \& Ingham 1965) and were assumed to be $A$. forsteri. However, since the 1981-82 summer, it has been established that both the subantarctic fur seal and the antarctic fur seal are breeding on North Head peninsula, but that the New Zealand fur seal, while present in larger numbers, does not breed (Shaughnessy \& Fletcher 1987).

Numbers of southern fur seals are recovering at many places, including Macquarie Island, but early stages of recovery have been little documented, especially the behavioural and social aspects. The opportunity for this is available at 


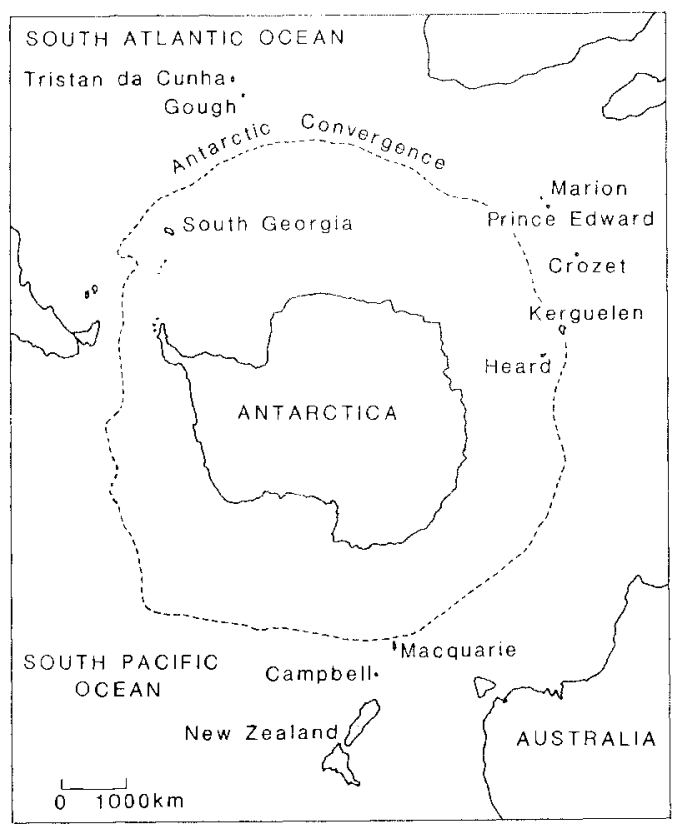

FIG. I - Subantarctic islands where southern fur seals breed.

Macquarie Island. The long-term aim of the project of which this forms a part is to document the population growth of fur seals at the island and to ascertain the relative roles of the species involved. Aspects of the breeding biology of $\boldsymbol{A}$. gazella and A. tropicalis in the 1985-86 and 1986-87 summers are described here; $A$. forsteri is discussed for comparative purposes and as it interacts with the two breeding species.

Elsewhere, the subantarctic fur seal breeds on islands north of the Antarctic Convergence in the South Indian and South Atlantic Oceans (fig. 1), particularly Gough, Marion, Amsterdam and the Crozet Archipelago. The antarctic fur seal breeds on island south of, or close to the Convergence, particularly at South Georgia, as well as Kerguelen and Heard. The New Zealand fur seal breeds in New Zealand, on its subantarctic islands, and on islands off the coast of South Australia and Western Australia (Bonner 1981).

\section{METHODS}

In the 1985-86 summer, Fletcher was present at Macquarie Island from 6 December until $14 \mathrm{March}$, and inspected the fur seals on North Head peninsula at intervals of one to two weeks. Field work by the other authors at Macquarie
Island extended from 7 December 1986 to 27 January 1987

In 1986-87, all fur seals on North Head peninsula were counted at weekly intervals. Breeding groups were visited at least three times per week, and numbers of animals were recorded in four categories: adult male, adult female, juvenile and pup. The adult male (bull) category included territory holders and large males that were resting or challenging. For $A$. gazella, small males were included in the bull category if they held a territory that included at least one cow and one pup, or if they challenged an $A$. tropicalis male that held a territory. The adult female class included animals with pups (i.e. cows), and animals of similar size and appearance that mixed with cows and were not driven away by bulls. Juveniles included animals smaller than cows, as well as males that were similar in size to cows but were chased away by bulls. Some animals on the fringe of territories were difficult to categorise, especially after midJanuary. They were included in the juvenile class unless they had a pup or were the size of large cows. Use of the term "pup" is restricted to animals with a black natal coat; it is shed after 3-4 months.

In 1986-87, all pups and many of the adult males and adult females of the two breeding species were individually marked with combinations of yellow, blue and white oil-based paint (International Yacht Enamel). Because of wear, these marks had to be renewed at intervals of seven to ten days. Pups were weighed at similar intervals with 10 and $15 \mathrm{~kg}$ Salter spring balances.

A total of 64 fur seals, comprising 36 pups, 20 adult females, 5 juveniles and 3 young males, were tagged in 1986-87. Tags were applied to the trailing edge of both foreflippers of pups at about one month of age or when their weight exceeded $8 \mathrm{~kg}$. Yellow plastic swivel tags (Jumbo Rototags) were used, inscribed with a four-digit number on each external surface and "Inform Antarctic Australia" on the internal surfaces. Other seals were also tagged on the foreflippers with the same series of tags, after it was ascertained that tagging would not cause undue disturbance. These animals were caught in a hoop net of $600 \mathrm{~mm}$ diameter with hessian inside the netting, and then restrained by one person.

\section{SPECIES IDENTIFICATION}

Species identification was based on pelage colour and pattern, facial profile, vocalisation, behaviour (particularly when approached by humans) and relative proportion of flippers to 


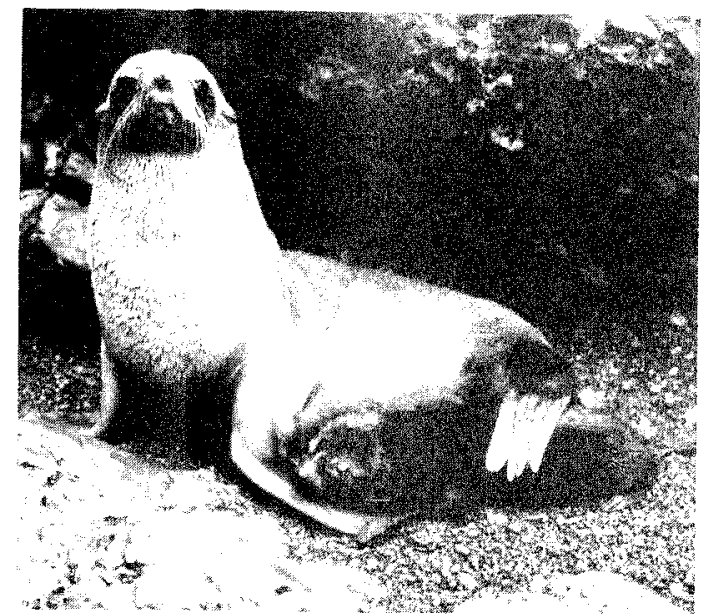

A

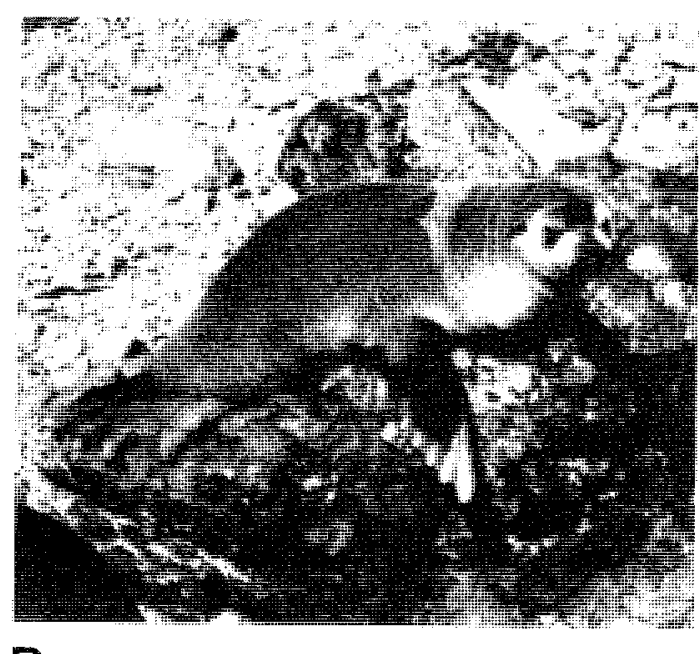

B

\section{PLATE I}

(A) Antarctic fur seal cow and (B) subantarctic fur seal cow, at Secluded Beach, Macquarie Island.

body length (Bonner 1968, Crawley \& Wilson 1976 , Condy 1978, Shaughnessy \& Fletcher 1987).

\section{Bulls}

A. tropicalis bulls were easily recognised by their distinctive creamy-coloured chest and face. Small males of this species have similar coloration. Their most common vocalisation was a repeated deep growl, as described by Paulian (1964).

A. gazella bulls are uniformly grey to dark brown, and thus somewhat similar in appearance to $A$. forsteri bulls. However, pelage of the latter

appears coarser and browner, and they have a longer, paler snout. In addition, the rhinarium is inflated and conspicuous in $A$. forsteri bulls, whereas it is smooth and inconspicuous in $A$. gazella (Bonner 1981). The most obvious distinction found between bulls of these two species was the habit of $A$. forsteri of growling and then fleeing when approached by humans; A. gazella bulls stood rheir ground and uttered rapid, wheezy exhalations which Bonner (1968) aptly described as whimpering. Vocalisations of $A$. iropicalis and $A$. gazella bulls were readily differentiated, as noted by Condy (1978) at Marion lsland.

\section{Cows}

The pelage of cows of both $A$. gazella and $A$. tropicalis is variable in coloration (Condy 1978), but the present studies found $A$. gazella cows tended to be lighter in colour, and had longer, more visible external ears covered with white hair (plate 1A). Cows of both species were paler on the ventral surface than the dorsal surface.

The nose and face of A. gazella cows tend to be longer and sharper than those of $A$. tropicalis cows. The latter have a short, broad nose, reminiscent of a Pekinese dog, and concave in profile. In juvenile and small $\boldsymbol{A}$. gazella the nose profile is convex, but it is slightly concave in larger $A$. gazella cows.

A useful feature for recognising large $A$. tropicalis cows is that the pale fur of the face extends above the eyes. Overall, large $A$. tropicalis cows have a similar pattern of coloration to bulls of the species (plate 1B).

Vocalisations are also useful for distinguishing between cows of the two species. In $A$. gazella the pup attraction call is higher pitched than the mournful wail of $A$. tropicalis. Cows of both species also have vocalisations similar to those of their bulls.

Pelage of $A$. forsteri cows has been described as uniformly brown (Crawley \& Wilson 1976). No cows fitting that description were seen in breeding territories at Macquarie, but seals of that coloration were seen elsewhere on North Head peninsula. They may have been cows (or juveniles) of $A$. forsteri, but they were not breeding.

\section{Pups}

Head shape and pelage coloration of pups of A. gazella, A. tropicalis and A. forsteri have been discussed by Shaughnessy \& Fletcher (1987). In brief, pups of $A$. gazella have a broad, flat head, 


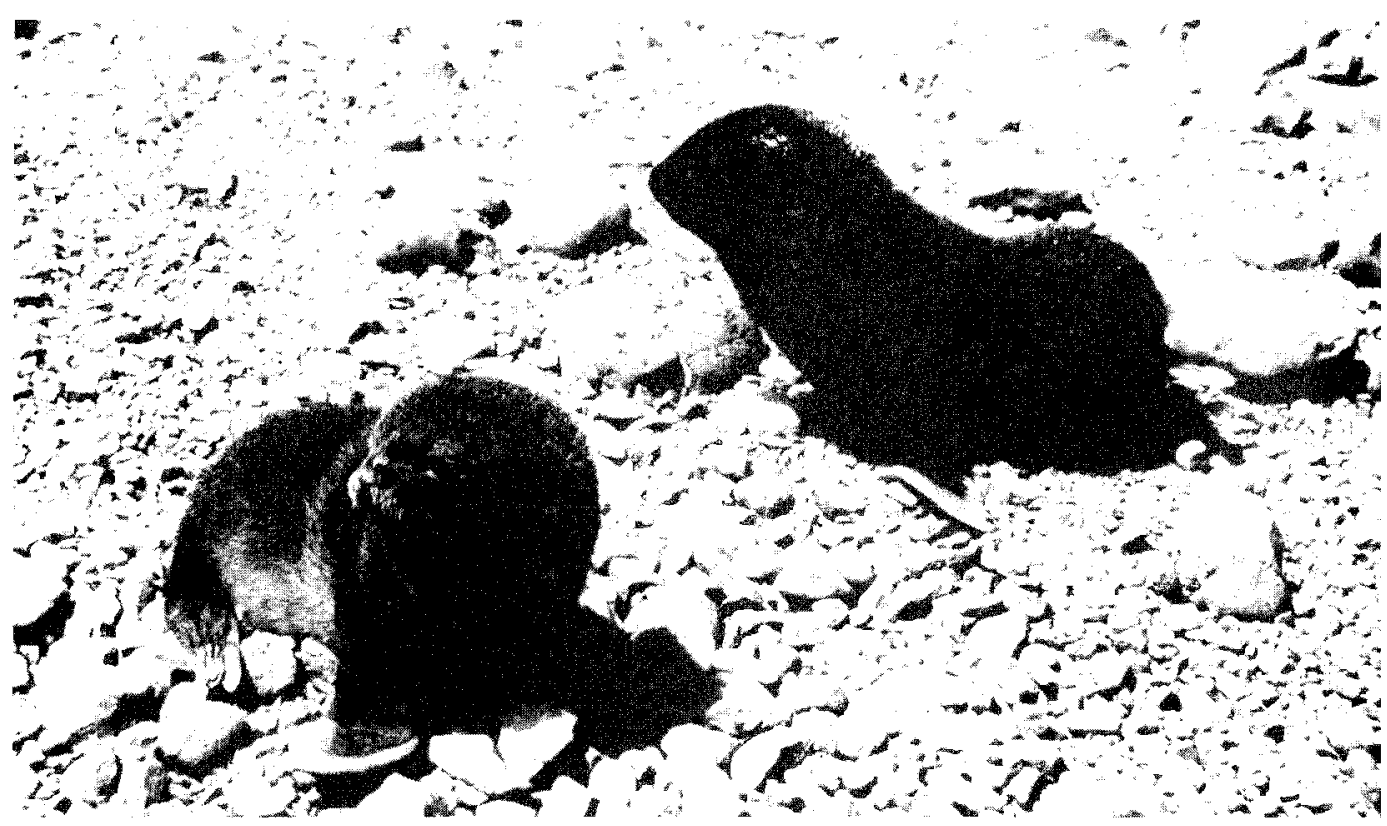

PLATE 2

Pups of the antarctic (left) and subantarctic (right) fur seal at Secluded Beach, Macquarie Island.

blunt snout and whitish muzzle, and the rest of the pelage is grizzled also. A. forsteri pups have a white muzzle, but their head profile is rounded. Pups of A. tropicalis have black pelage, including a black muzzle. At Macquarie Island, the differences in pelage and muzzle coloration between $A$. gazella and $A$. tropicalis became more apparent after the pups were a month old (plate 2).

No pups at Macquarie were recognised as having the characteristics of $A$. forsteri.

FIG. 2 - Map of North Head peninsula, Macquarie Island, showing localities where fur seals haul out.

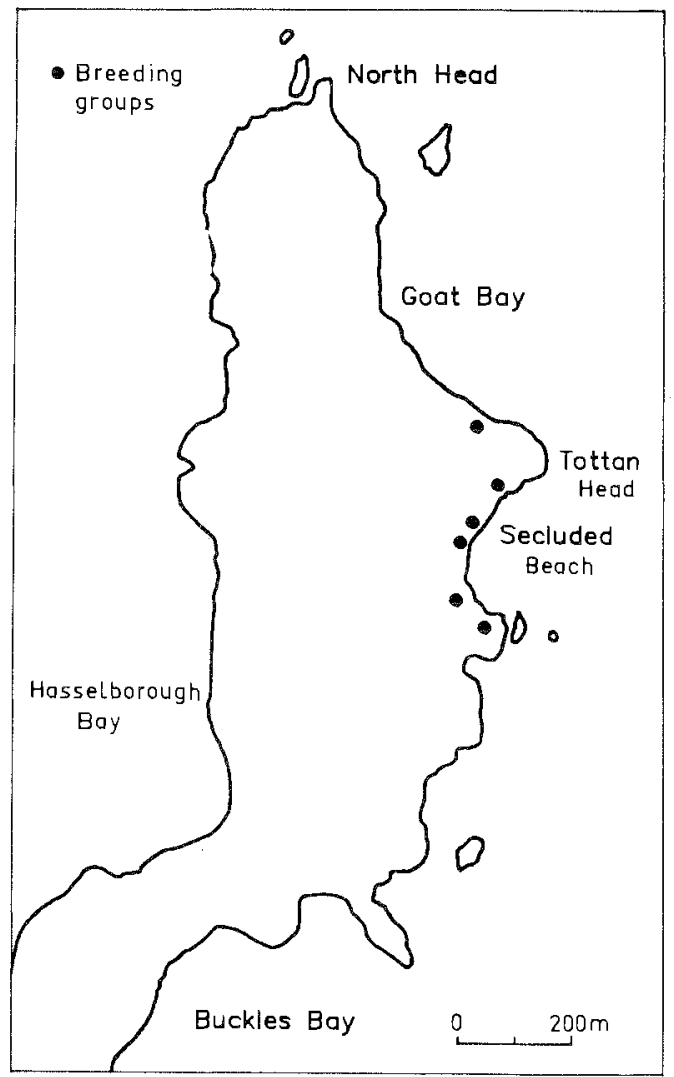




\section{HAULOUT LOCALITIES}

Most $A$. forsteri were seen on North Head peninsula, particularly at North Head and Goat Bay. None was recorded in breeding territories of A. gazella and A. tropicalis. The main concentrations of $A$. gazella and A. tropicalis were on the east coast of North Head peninsula ${ }_{9}$ on Secluded Beach and at the southern end of Goat Bay (fig. 2).

A single breeding group occupied a cove at the southern end of Goat Bay in both 1985-86 and 1986-87; this is one of the "Fur Seal Coves" recorded by Csordas \& Ingham (1965) as being frequented by fur seals from 1954-55 onwards. The breeding area is bounded on the northern and western sides by rocky walls, the substrate comprising pebbles interspersed with rocky outcrops $1 \mathrm{~m}$ high.

Secluded Beach consists of a pebble beach for most of its $300 \mathrm{~m}$ length; it is $20 \mathrm{~m}$ wide, with tussock slopes on the western (inland) side and rocks $1 \mathrm{~m}$ high in the intertidal zone on the eastern (seaward) side. The major breeding site, in terms of pup production in 1985-86 and 1986-87, was at the southern end beyond the pebble beach, and will be referred to here as South End. It is relatively flat and is bounded to the east by a rocky wall $3 \mathrm{~m}$ high and to the west by steep tussock slopes. The main access route to the sea is a gully to the southeast containing rounded rocks $0.2 \mathrm{~m}$ high; access to the north, over boulders $1 \mathrm{~m}$ high, was used by some cows but rarely by bulls.

In 1986-87, four smaller breeding groups (referred to here as, from south to north, South Beach, Pisa, Central and North End) were formed on Secluded Beach. South Beach was in a Ushaped cranny $2 \mathrm{~m}$ across, among rocks, with access to the sea over boulders $2 \mathrm{~m}$ high. Pisa was on the pebble beach, flanked on the south by a rock stack and extending to the water's edge. Central was also on the pebble beach and extended into intertidal rocks $1 \mathrm{~m}$ high. It was the least clearly defined territory, was frequently occupied by southern elephant seals (Mirounga leonina), and was the first territory to disperse. North End was at the northern end of Secluded Beach at the lower edge of tussock slopes, with access to the sea over a pebble beach and through the rocky intertidal zone. In 1985-86, three of these four sites (Pisa, Central and North End) were used. Juveniles belonging to the two breeding species came ashore on Secluded Beach, specially on the tussock slopes and pebble beach near its southern end, and near the breeding territory in Goat Bay.

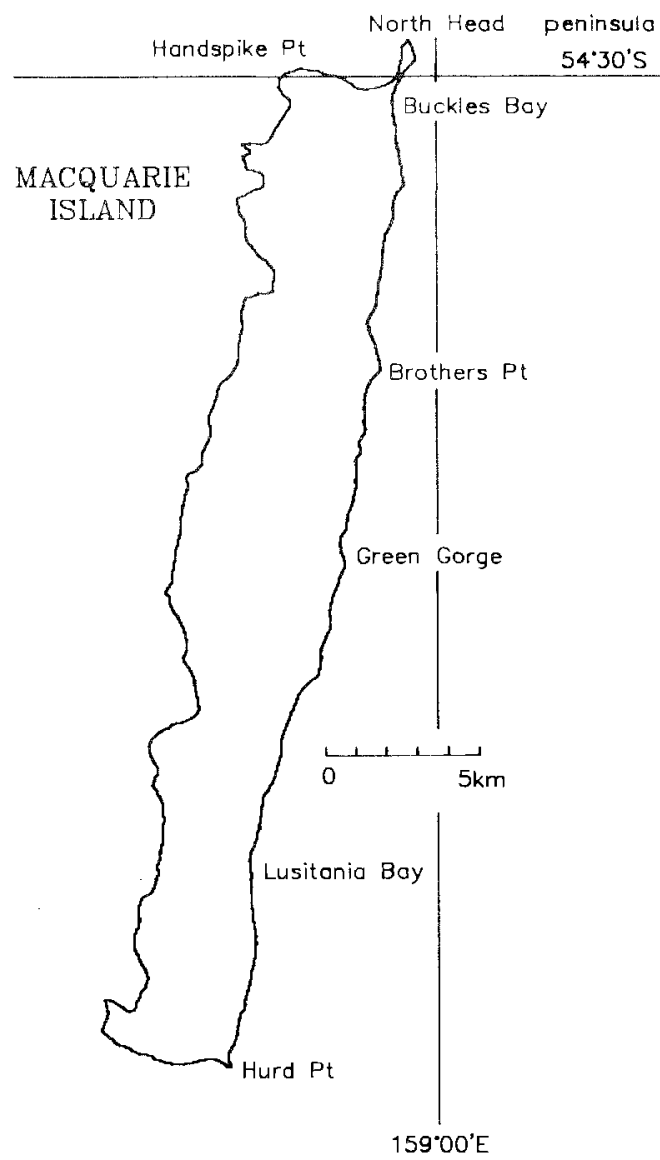

FIG. 3 - Map of Macquarie Island, showing localities where searches for fur seals were conducted.

On North Head peninsula, areas where $A$. forsteri hauled out contained larger rocks than areas preferred by $A$. gazella and $A$. tropicalis. In the terminology of Bester (1982) for habitat of $A$. tropicalis on Gough Island, $A$. forsteri prefers Jumbled Rocky Beaches, and the two breeding species prefer Intermediate Beaches (which have an irregular profile) and Exposed Boulder Beaches (which are more open).

Searches were made for fur seal pups at localities beyond North Head peninsula (fig. 3). In 1985-86, searches were made at Handspike Point (12 January), between Buckles Bay and Green Gorge (10 February and 12 March), between Lusitania Bay and Hurd Point (11 February), and at Hurd Point (27 February). In 1986-87 searches 


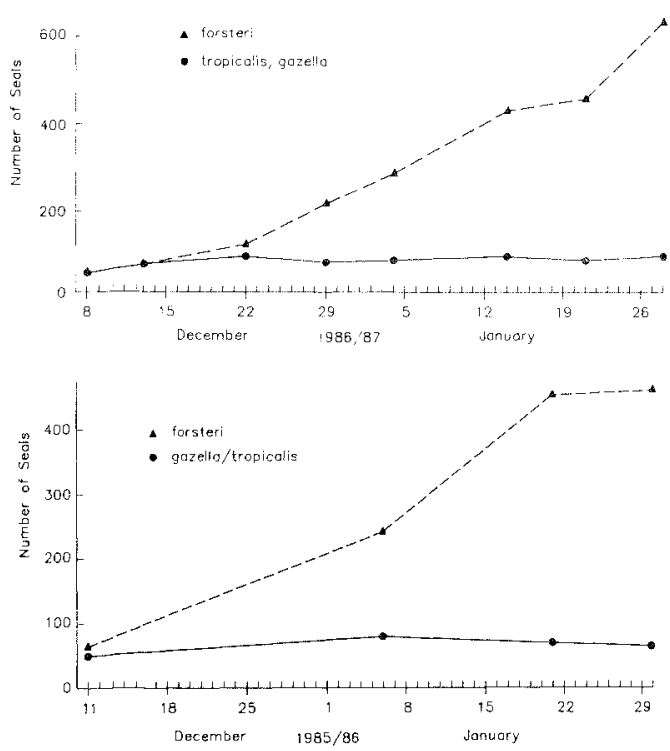

FIG. 4 - Counts offur seals (A. forsteri, A. gazella and A. tropicalis) on North Head peninsula, Macquarie Island, in the summers of $(A)$ 1986-87 and $(B)$ 1985-86.

were made at Handspike Point (15 December and 22 January), between Buckles Bay and Brothers Point (30 December, 2 January and 7 January), between Lusitania Bay and Hurd Point (20 January), and at Hurd Point (9 January). Small numbers of fur seals were seen at Handspike Point, Hurd Point and several sites on the east coast. Most were $A$. forsteri; no black pups, or adults of $A$. gazella or $A$. tropicalis were seen.

\section{COUNTS ON NORTH HEAD PENINSULA DURING SUMMER}

In the weekly counts around North Head peninsula, two groups of fur seals were distinguished: the two breeding species in one group and $A$. forsteri in the other. In 1986-87, the number of animals in each group was similar during early and mid-December (fig. 4A), being 50 to 70 animals. Subsequently, numbers of $A$. forsteri increased more rapidly than those of the other two species. In 1986-87, the latter group increased to 100 and then levelled off as territorial structures broke down and cows went to sea to feed. By the end of January, there were $660 \mathrm{~A}$. forsteri ashore, while the other two species together numbered only 105 .

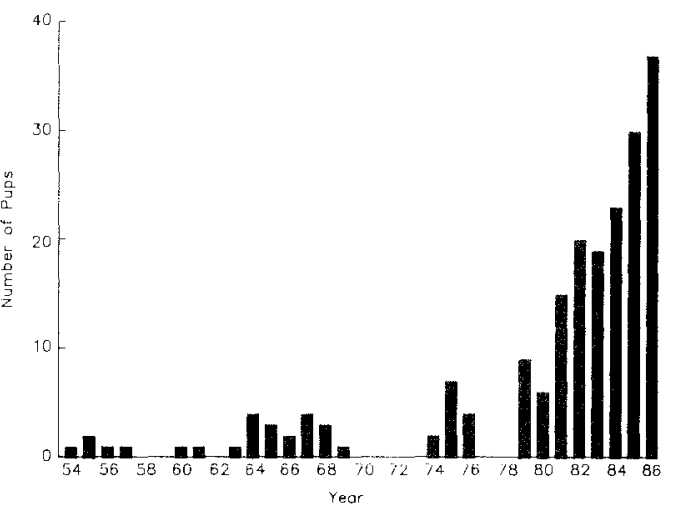

FIG. 5 - Numbers offur seal pups (A. gazella and A. tropicalis) recorded each summer on North Head peninsula, Macquarie Island. No attempt was made to record pup numbers in some years. "Year" refers to the end of a calendar year, since most pups are born in December.

Fewer data for 1985-86 (fig. 4B) showed similar trends, with slightly lower numbers for each species. This is partly explained by less of the $A$. forsteri habitat being included in the census in 1985-86. Furthermore, it is likely that the $A$. gazella/A. tropicalis group was undercounted in 1985-86, as $A$. gazella bulls were not recognised; it seems probable that small numbers of these were present (as in 1986-87) but were counted with $A$. forsteri bulls. Similar results were obtained in 1982-83 from less detailed counts (Shaughnessy \& Fletcher 1987, fig. 5).

Counts of fur seals on North Head peninsula are maximal in the period mid-February to early April (Csordas \& Ingham 1965). Therefore, the population census is taken in this period in most years. In March 1982, most (98\%) of the animals were recorded as $A$. forsteri in the annual census (Shaughnessy \& Fletcher 1987).

\section{PUPS AND THE PUPPING SEASON}

Numbers of pups recorded on North Head peninsula since 1954-55 show a gradual increase which has been most marked in the 1980's (fig. 5). These counts were made by many different observers and are of varying reliability. Numbers for 1985-86 and 1986-87 (30 and 37 pups respectively) exceed those of previous years.

Counts of pups made on visits to Secluded Beach in 1986-87 are illustrated in figure 6. Towards 
the end of January, pup numbers here were swelled by pups that moved from Goat Bay.

Fourteen pups had been born when the study began on 7 December; the last pup was born on 24 December. From simplified probit analysis (Caughley 1980), the median date of birth is calculated as 10 December with standard deviation 8.6 days. In $1985-86,18$ of the 30 pups born $(60 \%)$ were recorded at the time of the first visit on 11 December, suggesting that the median date of birth was similar to that for 1986-87. Shaughnessy \& Fletcher (1987) deduced, from less precise records kept by a va riety of observers over 12 seasons, that the pupping season at Macquarie Island extended from late November to mid-December.

Of the 37 pups born on North Head peninsula in 1986-87, 17 were male and 20 were female. This observed ratio of male to female does not differ significantly from a 1:1 sex ratio. Eight of the 37 pups were identified as $A$. tropicalis and 23 as $A$. gazella. The remaining six pups showed characteristics of both species.

Seven of the pups born in 1986-87 were weighed within 24 hours of birth. The average weight of five females was $4.12 \mathrm{~kg}$, with standard deviation of the mean $0.16 \mathrm{~kg}$. For two males, the average weight was $4.15 \mathrm{~kg}$.

Two of the 37 pups had died by the time of our departure in late January 1987. One of these was dead with umbilical cord still attached when first seen on 9 December; a cow was guarding it closely. The other was found drowned under rocks on 4 January. Another three pups were found dead in March and April. The pup mortality rate is

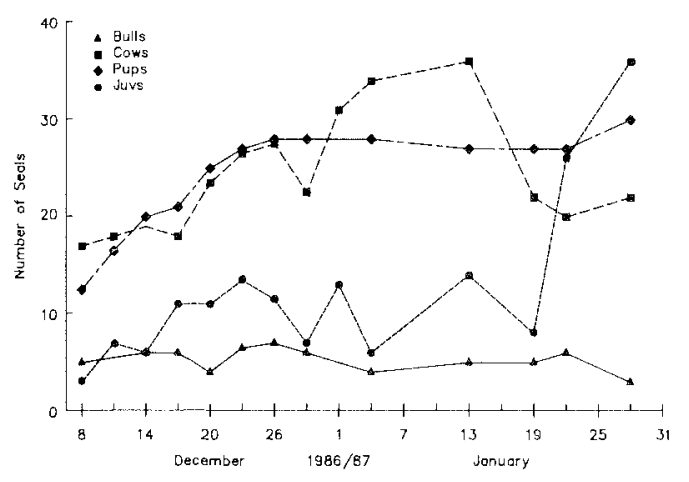

FIG.6 - Changes in numbers of breeding fur seals (A. gazella and A. tropicalis) in four age and sex classes, at Secluded Beach, Macquarie Island, during the 1986-87 summer. Counts in December have been averaged over three-day periods. therefore $5.4 \%$ to the end of January and $13.5 \%$ to the end of April.

The presence or absence of an umbilical cord on a newly discovered pup can provide useful information about its age, if it is known how long the cord is normally retained. Four pups were seen within 24 hours of birth, and so were of known age; for each of these, the umbilical cord was still attached after two days and had detached by the fourth day. Another five pups retained the umbilical cord for at least two days. Thus we deduce that umbilical cords of fur seal pups at Macquarie Island became detached between two and four days after birth.

\section{COMPOSITION OF BREEDING GROUPS IN 1986-87}

In 1986-87, 37 pups were born in six groups, five of which had already established when the study began. Eight pups were born in Goat Bay in a single territory. At Secluded Beach, there were five territories in which the following numbers of pups were born: $1,4,3,3$ and 18 . Three of the six territories ( 8,3 and 18 pups) were controlled solely by $A$. tropicalis bulls. The territory at Pisa (where three pups were born) was not established until 12 December. It was initially held by an $A$. gazella bull which was replaced nine days later by the $A$. tropicalis bull from the adjacent territory (Central). The Pisa group expanded in January, when several pups and their mothers moved there from other groups. The Central group (four pups) was initially held by an $A$. tropicalis bull, and then by each of several A. gazella bulls. An A. gazella bull (or bulls) was with the sixth group (one pup and its mother) on several occasions. From this account, which is summarised in table 1, it is apparent that most males holding territories were $A$. tropicalis.

That $A$. tropicalis bulls were in charge of more adult females and pups than were $A$. gazella bulls is further illustrated by the average number of bulls in charge of territories and the number of cows per bull on nine occasions between 7 December and 4 January (table 2).

The number of bulls ashore on North Head peninsula remained fairly constant during December and January in the 1986-87 season (fig. 6). By late December cows had spread out within territories and by early January territory structure was breaking down and territorial bulls were beginning to move away and be replaced by other bulls.

Seven $A$. tropicalis bulls were marked with paint; of these, four held territories and three were challengers. A. gazella bulls were more difficult to mark because they were not generally holding 


\section{TABLE 1}

Species composition of fur seals in breeding territories on North Head peninsula, Macquarie Island, in December 1986 and January 1987*

\begin{tabular}{|c|c|c|c|c|c|}
\hline \multirow{2}{*}{$\begin{array}{l}\text { Location of } \\
\text { breeding territory }\end{array}$} & \multicolumn{2}{|c|}{ Adult males** } & \multicolumn{3}{|c|}{ Pups** } \\
\hline & Bulls & Challengers & A.g. & A.t. & Unknown \\
\hline Goat Bay & A.t. & A.t. on $20 \mathrm{Jan}$ & 6 & 2 & - \\
\hline \multicolumn{6}{|l|}{ Secluded Beach } \\
\hline North End & $\begin{array}{l}\text { A.g. (various, } \\
\text { intermittent) }\end{array}$ & - & 1 & - & - \\
\hline Central & $\begin{array}{l}\text { A.t. then A.g. } \\
\text { (various) }\end{array}$ & - & 3 & - & 1 \\
\hline Pisa & $\begin{array}{l}\text { A.g. then A.t. } \\
\text { from Central }\end{array}$ & - & - & 1 & 2 \\
\hline South Beach & A.t. & - & 2 & 1 & - \\
\hline South End & A.t. & $\begin{array}{l}2 \text { A.t. (intermittent) } \\
\text { A.t. bull from South } \\
\text { Beach on } 2 \text { Jan only }\end{array}$ & $10^{* * *}$ & 4 & 3 \\
\hline
\end{tabular}

* Most cows were $A$. gazella; few were $A$. tropicalis.

** A.t. denotes $A$. tropicalis; A.g. denotes $A$. gazella.

*** Plus an $A$. gazella pup that died on 9 December.

territories and therefore could not be approached closely. Four of them were marked, but several more were present. Four marked $A$. tropicalis bulls that held territories remained in charge until the end of December (i.e. for the first 3-4 weeks of the study), whereas individual $A$. gazella bulls held territories for a few days only.

of antagonistic interactions recorded between males, the territory holder was $A$. tropicalis in 18 of 20 instances (table 3 ). No territory holders were seen to be displaced, although there was one change of ownership during December. In instances when the species of the challenger was identified, it

\section{TABLE 2}

Effectiveness of fur seal bulls of each species on North Head Peninsula, Macquarie Island, in the 1986-87 summer*

\begin{tabular}{llc} 
& A. tropicalis & A. gazella \\
\hline Number of bulls & & \\
$\quad$ Average & 4.1 & 1.0 \\
Range & $4-5$ & $0-2$ \\
$\quad$ Number of cows & & \\
per bull & & \\
$\quad$ Average & 6.3 & 1.8 \\
Range & $3.2-9.7$ & $1-3$ \\
\hline
\end{tabular}

* Data from nine days between 7 December and 4 January, at approximately three-day intervals. was $A$. gazella more frequently than $A$. tropicalis (10 of 16 occasions).

No bulls were measured, but $A$. tropicalis bulls appeared to be larger than $A$. gazella bulls, and therefore physically more able to win and hold a territory. A. gazella bulls were typically in one of three situations: in charge of a small group of cows and pups, on the edge of the largest territory (frequently in the shallows), or on pebble beaches of Secluded Beach, herding small groups of juveniles.

In 1986-87, no $A$. forsteri were recorded in breeding territories, although they were common on offshore rocks at the northern end of Secluded Beach. The presence of $A$. forsteri in territories after $A$. tropicalis bulls had left them was referred to by Shaughnessy \& Fletcher (1987). It is possible that these were $A$. gazella bulls mistaken for $A$. forsteri.

Almost all of the cows in territories were identified as $\boldsymbol{A}$. gazella; only a few $A$. tropicalis cows were seen (three certain).

The number of cows ashore (fig. 6) peaked in late December and again in mid-January. Timing of the former peak is similar to that of $A$. gazella cows at Marion Island (Kerley 1983a); the latter peak probably includes animals without pups (i.e. juveniles and adult females that were without pup this season). At South Georgia, cows of $A$. gazella stay ashore feeding their pups for about nine days post-partum and then move to sea to feed for 
TABLE 3

Antagonistic interactions between males of $A$. tropicalis (A.t.) and $A$. gazella (A.g.) on North Head peninsula during December 1986

\begin{tabular}{|c|c|c|c|c|c|c|c|c|}
\hline \multirow{2}{*}{$\begin{array}{l}\text { Territory } \\
\text { holder }\end{array}$} & \multicolumn{2}{|c|}{ Physical herding } & \multicolumn{3}{|c|}{ Chase } & \multicolumn{3}{|c|}{ Visual/aural } \\
\hline & A.t. & A.g. & A.t. & A.g. & $\begin{array}{l}\text { Unidentified } \\
\text { male* }\end{array}$ & A.t. & A.g. & $\begin{array}{l}\text { Unidentified } \\
\text { male* }\end{array}$ \\
\hline A tropicalis & 2 & - & 1 & 5 & 1 & 2 & 4 & 3 \\
\hline A. gazella & - & 1 & 1 & - & - & - & $\ldots$ & - \\
\hline
\end{tabular}

* The specific identity could not be determined for some small males.

several days at a time (Doidge et al. 1986). A similar behavioural pattern at Macquarie would explain fluctuations of their numbers in December and early January.

Copulation was seen on one occasion only, in 1986-87, on 22 December. This was between an $A$. tropicalis bull and an $A$. gazella cow. The cow had given birth between 12 and 13 December. Thus the mating was about 10 days post-partum. The cow went to sea on the following day for four days. Copulation of fur seals has not been reported previously at Macquarie Island.

The number of juveniles ashore increased markedly in late January (fig. 6). Most were on pebble beaches or in tussocks, away from breeding territories. In 1985-86, a similar increase was observed, continuing through February.

\section{TAG RESIGHTING}

One of the A. gazella cows tagged in 1986-87 was bearing a yellow plastic tag marked " 44 ". This indicated that she had been one of five pups tagged at Secluded Beach in February 1976 and was 11 years old in 1986-87. She was seen frequently with her pup at Secluded Beach during the summer. This is the strongest evidence yet available of a fur seal born at Macquarie Island returning to breed there. There have been several sightings of the 1976 tags in recent years (table 4), but this is the first occasion that one has been positively identified.

\section{RELATIONSHIPS WITH ELEPHANT SEALS}

Elephant seals also haul out at Goat Bay and Secluded Beach. During December and January (the fur seals' breeding season), elephant seals are ashore resting and/or moulting. Most are young animals, but subadult males and mature females in their fourth year haul out to moult by mid-January (Ling 1965).

No elephant seals were seen in the fur seals' breeding area in Goat Bay in the 1985-86 or 1986-87 summers. At Secluded Beach, small numbers were frequently within breeding territories

TABLE 4

Sightings of yellow plastic tags* on fur seals on North Head peninsula, Macquarie Island, since 1979-80

\begin{tabular}{|c|c|c|c|}
\hline Date & $\begin{array}{c}\text { Age } \\
\text { (years) }\end{array}$ & Location & Comments/source \\
\hline $23 \operatorname{Dec} 1979$ & 4 & Secluded Beach & Shaughnessy \& Fletcher (1987) \\
\hline 2 Dec 1983 & 8 & Goat Bay & $\begin{array}{l}\text { Cow; pup not visible, but cow behaved as if } \\
\text { she had a pup (G. Copson, pers. comm.) }\end{array}$ \\
\hline 2 Jan 1984 & 8 & Goat Bay & as above \\
\hline $16 \operatorname{Dec} 1985$ & 10 & Goat Bay & Cow; not sighted on subsequent visits \\
\hline 7 Dec 1986 & 11 & Goat Bay & as above \\
\hline $\begin{array}{l}\text { Dec } 86 \\
\text { (several occasions) }\end{array}$ & 11 & Secluded Beach & $\begin{array}{l}\text { Cow with pup, seen frequently. Tag number } \\
44 \text {, retagged } R \text { foreflipper } 0002\end{array}$ \\
\hline
\end{tabular}

\footnotetext{
* These tags were applied to five pups in February 1976.
} 
of the fur seals, especially at the territory known as Central. For example, on 10 December 1986 that territory included four juvenile elephant seals (aged three months), as well as four fur seal cows and two pups. Fur seals were usually sufficiently attentive and nimble to climb over recumbent elephant seals or to d odge moving ones.

Two young elephant seals remained in the large fur seal territory at the southern end of Secluded Beach for a week from 14 December 1986. Several pups were observed receiving openmouthed threats from the elephant seals, which resulted in their being almost engulfed in the elephant seals' capacious mouths.

\section{BARNACLES}

$B$ arnacles were seen to be infesting the pelage of several A. gazella cows in territories, early in the observation period of 1986-87. A small number collected from the flank of one cow were identified as juvenile Lepas australis (T. Cochran, Museum of Victoria, pers. comm.). This species is distributed in the Southern Hemisphere in cold temperate to antarctic waters (Foster 1978). There is a previous record of the species from the vicinity of Macquarie Island (Foster 1978); it has also been found on $A$. gazella at South Georgia (Bonner 1968).

\section{DISCUSSION AND CONCLUSIONS}

A. gazella and $A$. tropicalis are sympatric at Macquarie Island, as well as at Possession Island in the Crozet Archipelago (Jouventin et al. 1982) and at Marion Island (Condy 1978, Kerley 1983b). At the last two localities, $A$. tropicalis is the more abundant species, contrary to the situation at Macquarie Island.

At Marion Island, most $A$, gazella were separate from groups of $A$. tropicalis, but mixed groups were recorded. Hybridisation was strongly suspected at Marion Island, on the basis of sightings of adult males with external characteristics of both species (Condy 1978, Kerley 1983b). Hybridisation was considered probable at Crozet, because both species were present in some breeding territories (Jouventin et al. 1982). At Macquarie Island in 1986-87, the five breeding territories with more than one cow contained adults of both species. Hybridisation is suspected because six of the 37 pups appeared to have characteristics of both species. However, no apparently hybrid adults were seen. As noted previously, the only copulation observed at Macquarie was between an $A$. tropicalis male and an $A$. gazella female.
The question of hybridisation could be clarified by an electrophoretic examination of proteins and enzymes in blood samples from pups. As differences have already been demonstrated in the serum protein transferrin for several species of Arctocephalus, including those at Macquarie Island (Shaughnessy 1970, Kerley 1984), hybrids should be detectable by this means.

At Macquarie Island in 1986-87, most territorial bulls were $A$. tropicalis and most cows were A. gazella. If $A$. gazella cows in territories were not impregnated in 1986-87, they are less likely to frequent the breeding territories in 1987-88 than in 1986-87. Consequently, in the later season they are more likely to be mated by an $A$. gazella male on the periphery of a territory or on the pebble beaches than during the earlier season, when they were actively herded by $A$. tropicalis males in territories and $A$. gazella males were denied access to them.

This idea could be tested in 1987-88 by searching for cows tagged in 1986-87. If it is correct, a corollary would be that cows should appear in breeding territories in 1987-88 that were not seen there in 1986-87. It would imply, furthermore, that the recruitment rate of the population is very low, and any increase in the population will be slow until some $A$. gazella bulls grow to sufficient size to win and hold territories from $A$. tropicalis bulls.

Fur seal mothers and their pups are particularly susceptible to disturbance soon after birth when the mother-pup bond is being established. Therefore we recommend that, while the population level is low, access to Goat Bay and Secluded Beach be restricted during the pupping season in order to limit disturbance.

A. gazella has been reported previously as breeding in Australian waters at Heard Island (Budd \& Downes 1969). This study confirms that, as proposed by Shaughnessy \& Fletcher (1987), $A$. tropicalis also breeds on Australian territory.

\section{ACKNOWLEDGEMENTS}

We are grateful to the Australian Antarctic Division and to the National Parks and Wildlife Service, Tasmania, for making the visits possible, and especially to H. Burton and G. Copson. We also thank the many expeditioners who assisted in the field. Support was provided by the Australian Antarctic Science Grants Scheme in 1986-87, when the study was sponsored by the Antarctic Society of Australia. 


\section{REFERENCES}

BESTER, M.N., 1982: Distribution, habitat selection and colony types of the Amsterdam Island fur Seal Arctocephalus tropicalis at Gough Island. J. Zool. (Lond.), 196: 217-231.

BONNER, W.N., 1968: The fur seal of South Georgia. Brit. Antarct. Surv. Sci. Rep., 56: 1-81.

BONNER, W.N., 1981: Southern fur seals Arctocephalus (Geoffroy Saint-Hilaire and Cuvier, 1826). In Ridgway, S.H. \& Harrison, R.J. (Eds): $H A N D$ BOOK OF MARINE MAMMALS. VOL.I. Academic Press, London: 161-208.

BUDD, G.M. \& DOWNES, M.C., 1969: Population increase and breeding in the Kerguelen fur seal, Arctocephalus tropicalis gazella, at Heard Isiand. Mammalia, 33: 58-67.

CAUGHLEY, G., 1980: ANALYSIS OF VERTEBRATE POPULATIONS. Wiley, London.

CONDY, P.R., 1978: Distribution, abundance, and annual cycle of fur seals (Arctocephalus spp.) on the Prince Edward Islands. $S$. Afr. $J$. Wildl. Res., 8: 159-168.

CRAWLEY, M.C. \& WILSON, G.J., 1976: The natural history and behaviour of the New Zealand fur seal (Arctocephalus forsteri). Tuatara, 22: 1-29.

CSORDAS, S.E. \& INGHAM, S.E., 1965: The New Zealand fur seal, Arctocephalus forsteri (Lesson) at Macquarie Island. CSIRO Wildl. Res., 10: 83-99.

CUMPSTON, J.S., 1968: Macquarie Island. $A N A R E$ Sci. Rep., Ser A(1): 1-380.

DOIDGE, D.W., MCCANN, T.S. \& CROXALL, J.P., 1986: Attendance behaviour of Antarctic fur seals. In Gentry, R.L. \& Kooyman, G.L. (Eds): FUR SEALS: MATERNAL STRATEGIES $O N L A N D A N D A T S E A$. Princeton University Press, Princeton: 102-114.
FOSTER, B.A., 1978: The marine fauna of New Zealand: barnacles (Cirripedia: Thoracica). N.Z. Oceanogr. Inst. Mem., 69:5-160.

GWYNN, A.M 1953: Notes on the fur seals at Macquarie Island and Heard Island. ANARE Int. Rep., 4: 1-16.

JOUVENTIN, P., STAHL, J.C. \& WEIMERSKIRCH, H., 1982: La recolonisation des Iles Crozet par les otaries (Arctocephalus tropicalis et $A$ gezzella). Mammalia, 46: 505-514.

KERLEY, G.1.H., 1983a: Comparison of seasonal haulout patterns of fur seals Arctocephalus tropicalis and A. gazello on subantarctic Marion Island. $S$ Afr. J. Wildl. Res., 13:71-77.

KERLEY, G.I.H., 1983b: Relative population sizes and trends, and hybridization of fur seals Arctocephalus tropicalis and A. gazella at the Prince Edward Islands, Southern Ocean. $S$. Afr. $J$. Zool., 18: 388-392.

KERLEY, G.I.H., 1984: Relationships between sympatric breeding populations of fur seals (Arctocephalus sp.) at the Prince Edward Islands. $S$. Afr. J. Sci., 80: 28-29.

LING, J.K., 1965: Hair growth and moulting in the southern elephant seal Mirounga leonina (Linn.). In Lyne, A.G. \& Short, B.F. (Eds): BIOLOGY OF THE SKIN AND HAIR GROWTH. Angus and Robertson, Sydney: 525-544.

PAULIAN, P., 1964: Contribution a l'etude de l'otarie de lile Amsterdam. Mammalia, 28, suppl. 1: 3-146.

SHAUGHNESSY, P.D., 1970: Serum protein variation in southern fur seals, Arctocephalus spp., in relation to their taxonomy. Aust. J. Zool., 18: 331-343.

SHAUGHNESSY, P.D. \& FLETCHER, L., 1987: Fur seals, Arctocephalus spp., at Macquarie Island. NOAA Tech. Rep. NMFS 5I: 177-188.

(accepted 22 January 1988) 